\title{
Motives, Expectations, Perceptions and Satisfaction of International Students Pursuing Private Higher Education in Singapore
}

\author{
Sein Min $^{1}$, Chey Chor Khoon ${ }^{2} \&$ Boon Leing Tan ${ }^{1}$ \\ ${ }^{1}$ MDIS Business School, Singapore City, Singapore \\ ${ }^{2}$ Nanyang Technological University, Nanyang Avenue, Singapore \\ Correspondence: Sein Min, MDIS Business School, Singapore City, Singapore. E-mail: sein_min@mdis.edu.sg
}

Received: August 4, 2012 Accepted: August 29, 2012 Online Published: November 7, 2012

doi:10.5539/ijms.v4n6p122 URL: http://dx.doi.org/10.5539/ijms.v4n6p122

\begin{abstract}
As education is an important sector in every national economy, it is arguable that higher education is a key area of interest of both public and private institutions. With globalization, the higher education sector is internationalized through the mobility of the institutions and students alike. International students are increasingly moving to other countries in pursuit of education and other interests such as career opportunities, cultural and social experiences, and even migration.
\end{abstract}

The present study investigates international students' motives in studying abroad and the impacts of these different motives on their evaluation of service quality of the institutions where they study. This study attempts to incorporate the motives of their study with the well recognized service quality model, namely SERVQUAL.

This study was empirically conducted in a private higher education institution in Singapore, gathering data from 263 international students who are studying in the business programmes. The survey method was used to gather the required data about the motives, expectations and perceptions as well as the level of satisfaction with the education service provided by the institution under study.

The study found that the students held four kinds of motives: academic \& education, career \& migration, pleasure \& experience and work. The study suggests that educational marketers should consider the role and influence of the motives in evaluating service quality by international students and to develop their education programmes accordingly so that their level of service quality will be enhanced from the perspective of international students.

Keywords: education marketing, higher education, service quality, motives, SERVQUAL, customer satisfaction

\section{Introduction}

The education sector is an important contributor to every national economy, as a substantial amount of public spending is invested in this sector which generates a large number of employment. Within this sector, special attention needs to be paid to private higher education in which most of mobile (international) students are studying. This is because of the large sums of money spent by a growing number of people in this activity. According to the World Bank, spending on higher education approached US\$400 billion in 2006 (Bjarnason, Cheng, Fielden, Lemaitre, Levy \& Varghese, 2009, p. 16) and, according to the UNESCO Institute of Statistics (UIS), in 2009, about 3.4 million students are enrolled outside their country of citizenship (cited by Choudaha \& Chang, 2012, p. 6). In line with the globalization of services, higher education services are internationalized in which the mobility of institutions as well as students are taking place (Harman, 2001; Kritz, 2006; Perkinson, 2006; Vincent-Lancrin, 2008; Baier, 2009).

Higher education is seen nowadays as an international service industry (i.e. business activity) engaged by both public and private institutions. The sheer number as well as the growth rate of students in tertiary education indicate the increasing importance of the higher education sector and hence the need for systematic approach to achieve the goals of the participants in the industry (Gupta, 2005; Hammond, Webster \& Harmon, 2006; Rindfresh, 2003).

Singapore is one of the major host countries in Asia for international students. By 2010, 48,623 international (mobile) students studied in tertiary education of Singapore (UIS, 2012). Singapore is a city that "offers a more 
alluring mix of cutting-edge infrastructure, world-class education system and dynamic cosmopolitan vibe thanks to a blend of Eastern and Western cultures" (Singapore Education, 2006, para. 2). Her reputation for efficiency, cleanliness, rule of law, among others, have made it a favourite place of study for many foreign students, most of whom come from China, India and the neighbouring Southeast Asian countries. The government of Singapore has strived to position Singapore as an educational hub in Southeast Asia, setting the target of attracting 150,000 foreign students to study here particularly at higher education level, by the year 2015 (Economic Review Committee, 2003, p. 160).

International students studying in a foreign country are driven by various motives and hold different expectations (Wang, 2004; MITC, 2010). Basically, their motives can be classified into (a) seeking academic quality, and (b) seeking opportunities (such as employment, migration, experience and exposure). As Sherry, Thomas and Chui (2009) point out, citing Andrade (2006) and McClure (2007), "students want to explore different cultures, learn new ways of thinking and behaving, make new friends, and improve their cross-cultural knowledge and skills" (p. 33). The immersion in another culture often helps international students attain higher levels of self-esteem and confidence.

As the higher education industry becomes increasingly competitive, marketers in this industry are required to improve their service quality through understanding the attributes of an excellent college or university and through narrowing the gap between the expectations and perception of the educational services (Arambewela \& Hill, 2006; Barnes, 2007; Shekarchizadeh, Rash \& Hon-Tat (2011). The primary reasons (motives) of the students for studying abroad are believed to be underlying factors in assessing the service quality. The motives of the international students can have a major influence on the process of determining the quality of educational services.

Many studies explore various aspects of international education, including the reasons for studying overseas (Vincent-Lancrin, 2008; British Council, 2008; Arora, 2007), and assessment of the educational service quality (Arambewela \& Hall, 2006; Katty, Catherine \& Tin (2009). However, the relationship between the motives of the study and the assessment on the service quality has not yet been investigated adequately. The motives of the international students pursuing higher education in Singapore and their impacts on the assessment on the service quality have been chosen as the focus of the current research.

This study aims to investigate the role of the motives of studying abroad in international students' judgment of the service quality of private higher education institutions. We hypothesize that the motives of the international students can be a crucial element in the expectation and perception of service quality and hence the level of satisfaction with regard to the service that international students receive.

\section{Literature Review}

\subsection{Service Quality}

As a key area of interest in creating a successful educational institution, attention is increasingly being paid towards the 'service quality' of education programmes. Students' retention and their performance depend on the service quality of the institution concerned (Sanders, Stevenson, King \& Coates, 2000).

To study service quality in the higher education sector, the well-known SERVQUAL framework is applied by many researchers. For instance, Arambewela and Hall (2006) examined the relationship between SERVQUAL constructs proposed by Parasuraman, Zeithaml and Berry $(1985,1988)$ and the country of origin and satisfaction among four cohorts of international postgraduate students from China, India, Indonesia and Thailand studying in Australian universities. Barnes (2007) analysed service quality among a sample of Chinese postgraduate students with the aim of finding out the service 'gap' between expectations and perceptions. SERVQUAL is also able to show some satisfactory results in the education services (Michael \& Pamela, 2008; Atrek, 2010). The five key dimensions of services in SERVQUAL are: responsiveness, assurance, tangibility, empathy and reliability. For the measurement of each dimension, it was necessary to develop education-specific items. Barnes (2007) conducted a survey to study the expectations and perceptions of Chinese postgraduate students in a business and management school in UK, applying the specific items for SERVQUAL's original dimensions as shown in the Figure 1. 


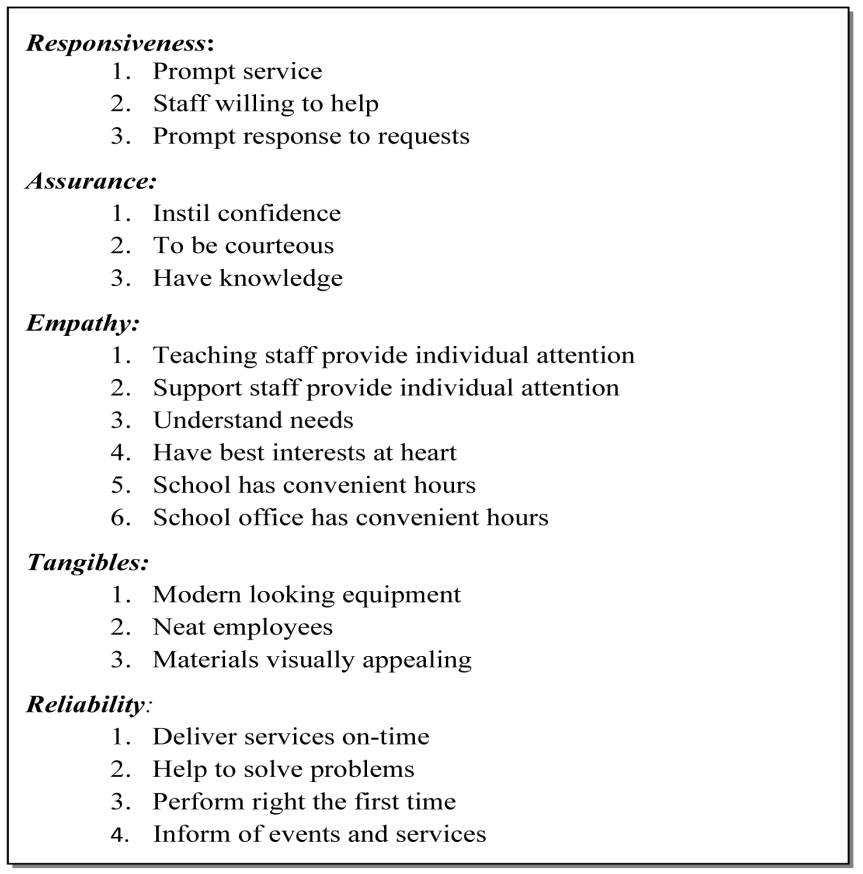

Figure 1. The original five dimensions of SERVQUAL in the study by Bernes (2007)

Source: Barnes (2007, p. 321)

SERVQUAL evaluates service quality by comparing the expectation in each dimension and individual item, with the perceived level. The narrower the gap the higher is the level of customer satisfaction. It is a useful and effective method of measuring service quality, particularly in the touchpoints with customers. Actual service quality goes beyond the touchpoints with customers. It is concerned with the benefits of the service even after the service has been rendered. For example, education service quality is not just to pay attention to individuals; the education programme is able to help the students to easily get employed or to be recognized by others. To be excellent in university level education, the service dimensions should also include reputation, career opportunities, programme issues, physical aspects and location, as suggested by some researchers (Barnes, 2007). Perceived quality of a university is also related to the characteristics of the university such as teaching, facilities, class size, student's workload, etc. A particular application of SERVQUAL in the students' ratings on the teaching is found in the work of Chatterjee, Ghosh and Bandyopadhyay (2009) that uses such service parameters as general knowledge along with academic excellence, ability to teach, and mode of presentation.

\subsection{Motives of Studying Abroad}

Measurement and evaluation of service quality is subjective as it uses individual judgment based on psychological factors such as motive, attitude, perception, etc. A study about the process of service and determination of service quality outcome needs to consider psychological factors of customers. In higher education, students pursue their education programmes with different underlying motives that affect their decision to study abroad; the selection of a destination country, school and subjects. Many studies were conducted in the past about the reasons or motives of foreign students studying abroad (British Council, 2008). Firstly the choice between studying at home and studying abroad even for the same programme offered by a well reputed university is dependent on the perspective of potential employers who may rate studying abroad higher than studying at home, thus leading students to want to be internationally educated graduates (British Council, 2008).

Wang (2004), cited also by Poh and Townsend (2008), developed a typology of motives of foreign students in which three 'primary' motives of international students are classified as:

- Academic (seeking purely high quality, high standard education with recognition from employers, quality teaching, seriously studying) 
- Career (seeking opportunities to get a job, now or later, attracted by job market conditions in the host country, aiming to settle down in the host country, i.e. migration)

- Experiential (putting high value on the experience of staying abroad, particularly the host country of study, looking for opportunities to actively participate in social and cultural events, expecting to meet with people from different countries, learning the international culture and host country's culture).

A study of Vietnamese students conducted by Maine International Trade Centre (MITC, 2010) found the following reasons for studying abroad by Vietnamese students:

1) Quality of education

2) Cultural experience

3) To improve language skills

4) To prepare for a future

5) To obtain a degree

6) To become professional

Similarly, a study by Baier (2009) of the foreign students in BTU found that the motives for studying in Germany were:

1) Improving career opportunities

2) German universities having good reputations

3) No tuition fees

The causes and factors of student mobility are the focus of interest in world population and migration studies. It was noted that the decision to study abroad and the decision where to study depend on a broad spectrum of cultural, educational, economic and social factors. Vincent-Lancrin (2008) stated the factors that influence a student's decision regarding where to study, as listed in Figure 2.

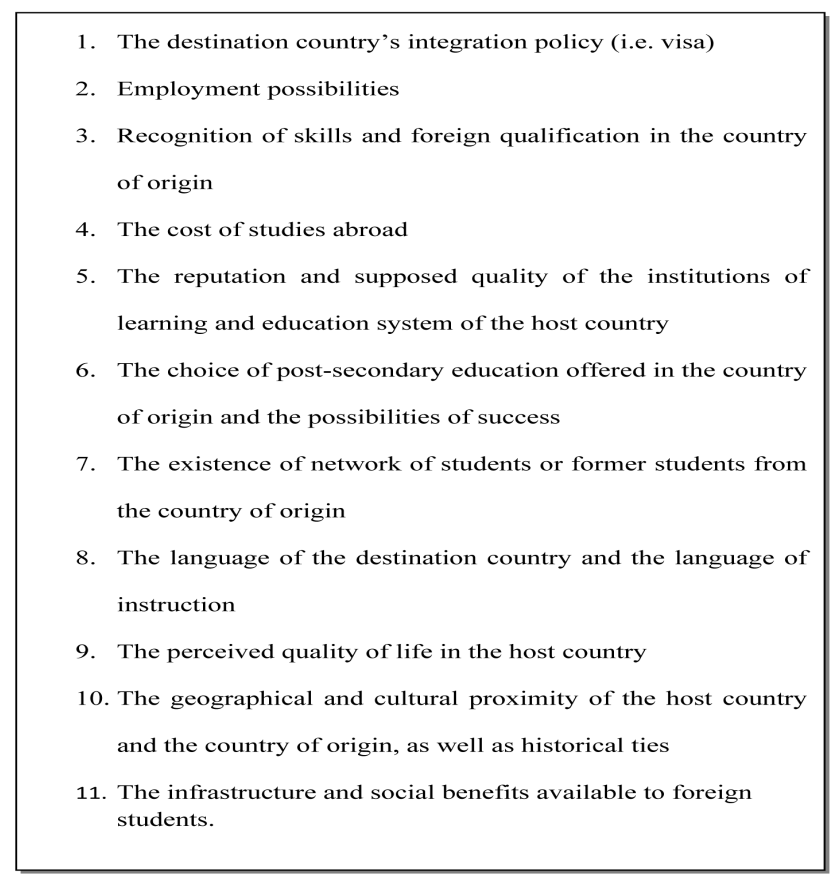

Figure 2. Factors influencing students' decision where to study

Source: Adapted from Vincent-Lancrin (2008, pp. 111-112)

In the study by Poh and Townsend (2008) of a group of students of Chinese ethnic background from various countries, it was found that the main intention in studying abroad was entirely due to educational factors, which 
was supported by the findings by Wang (2004). International students intend to gain knowledge and improvement in their field of specialization and, for some, to prepare for a higher degree. In the competitive job market, it is also important for the students to graduate from a prestigious university and hence university image is also one of the factors in the decision-making of students who are looking for future opportunities (Poh \& Townsend, 2008).

\section{Methodology}

\subsection{Research Design and Methods}

The present research attempts to identify the key motives of international (mobile) students using the sample survey method. To identify motives of study by each sample student, a measurement instrument using scaling technique was developed. For measuring service quality, the SERVQUAL framework was employed with some modifications. The research eventually examined the causal relationships between motives of the study and service quality as well as between the motives and the overall satisfaction with the programme.

The questions concerning the motives, expectation of service quality, the actual experience with the service quality (perceived) service quality, and the overall satisfaction, include the Likert's five points scale with multiple statements for each dimension. The statements were developed based on the existing frameworks and studies found in the literature. The motive statements were analysed with the factor analysis and developed into major components. For the service quality, SERVQUAL model was applied and the statements in each SERVQUAL components were validated by the factor analysis. The statements under the measurement of satisfaction were also validated by the factor analysis. For each component, the aggregate score was computed and used for testing hypotheses and analysis.

The survey results were firstly checked for reliability using Cronbach's Alpha to evaluate the reliability of the scales used in this study. Together with the reliability test, the validity of the factors / components was checked with the KMO (Kaiser-Meyer-Olkin)'s measure of sampling adequacy.

Based on the literature review, the key elements of the study were formulated into hypotheses which were then tested with appropriate methods. The test methods used in the hypothesis test are nonparametric test (Friedman Test), mean-test (t-Test) and correlation.

\subsection{Analytical Framework for the Research}

International students hold presumably different goals and motives for their studies notwithstanding their common goal of preparing for the future. In our study, Wang (2004)'s typology of motives of foreign students, namely academic, career and experiential, is adopted as the basic framework of the construct for the variable, motive.

The task of marketing is to maximize customer's satisfaction, by narrowing the service gap. This is done by understanding the condition of each service element and dimension. For the measurement and evaluation of service quality, the SERVQUAL framework can be adopted, but it is necessary to modify and expand it so as to reflect the specific nature and condition of higher education market. The modified SERVQUAL framework which is found in the work of Barnes (2007) will be extended further so that the service quality is not just for the 'service operation' and 'service process', but also the real benefits of service as a product. Hence, the new extended framework will be used for the measurement and evaluation of quality of 'service product'.

The conceptual framework for this study consists therefore of three main components: motive of study, service product quality (expectation and perception) and outcome (satisfaction or dissatisfaction). The relationships of these three main components are moderated by the demographic variables as shown in Figure 3.

\section{MOTIVES}

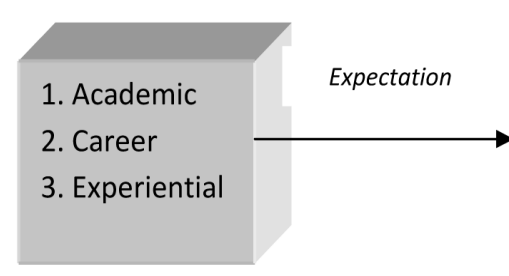

SERVICE QUALITY

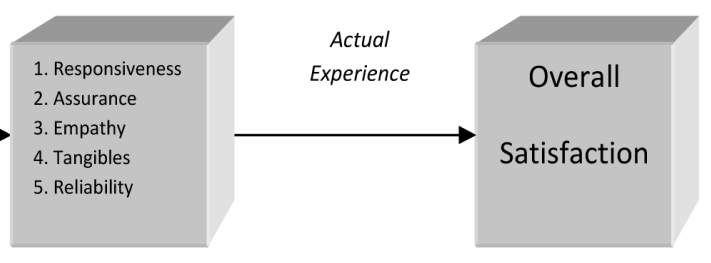

Figure 3. Simplified model of service process in the higher education 


\subsection{Hypothesis Development}

In line with the research objectives set out earlier, hypotheses have been developed in three areas. The first area of interest of this research is whether the motives of international students who are studying in private schools of higher education differ significantly or not. International students are diverse in their origins and cultural and economic backgrounds as well as motives of their study abroad. The motives can also differ due to individual personal factors. For example, a student from a wealthy family can spend a larger amount of money than others whose parents are not rich. The latter families send their children to study abroad, considering the study as an investment for the good future of their children. The current researchers hold the view that the student in the latter group will be more serious in his/her studies than the former. If a student has more financial constraints than the others, he or she might be more interested in taking a shorter course and then to find a job in Singapore.

H1: International students studying in Singapore private higher education hold significantly different motives of study. (The levels of motives of study differ from each other.)

Like the studies in the past which examined the influence of country of origin on the service quality, the motives can have also an effect on the expectation and perception of service quality. For a given service (education programme), students with different motives of study will show different views, feelings and satisfaction. To study the relationships between motivation, service quality and satisfaction, the research process is divided into two parts; the first is to test the relationship between the motive and service quality (expectations, perception and service gap) $\{\mathrm{H} 2 \mathrm{~A}, \mathrm{H} 2 \mathrm{~B}, \mathrm{H} 2 \mathrm{C}$ and $\mathrm{H} 2 \mathrm{D}$ ), while the second is to test the impact of service quality on customer (student) satisfaction with $\mathrm{H} 3$

H2A: Expectation of service quality is related to the motive of study. (The higher the level of motive, the higher is the level of expectation of service quality.)

H2B: Perception of service quality is related to the motive of study. (The higher the level of motive, the higher is the perceived level of service quality.)

H2C: Service gap is related to the motive of study. (The higher the level of motive, the lower is the gap of service.)

H2D: Satisfaction level is related to the motive of study. (The higher the level of motive, the higher is the level of satisfaction.)

H3: The satisfaction is related to the service quality measured by the gap. (The narrower the gap in the service quality, the higher is the satisfaction.)

The hypotheses (H2A, H2B, H2C and H2D) are concerned with the construct validity of motive concept. H3 is concerned with the construct validity of service quality concept.

\subsection{Questionnaire Design}

The questionnaire consists of six parts: measurement of motive of study, measurement of service quality, measurement of overall satisfaction level, problems and difficulties, and respondent's demographics. The first four parts use the itemized rating scale. The motive, expectation of the service dimensions, and satisfaction are measured by the Likert's five points scale. The third part of the questionnaire deals with the evaluation of actual perceived level of service dimensions. The scale used has five levels similar to the Likert's scale, specifically 'very poor' (1), 'poor' (2), 'average' (3), 'good' (4), and 'very good' (5). The last section of the questionnaire will deal with respondent's demographics such as gender, age, nationality, etc.

\subsection{Sample Design}

The study chose a leading Private Education Institution (PEI) in Singapore where international students from China, India, Vietnam, Indonesian and other countries were studying. Moreover, samples were drawn only from the business school in that PEI. The rationale for including just one PEI in this study is that the conceptual model and its internal validity should be tested before proceeding to the large scale, representative study of the entire Singapore education scene to achieve the external validity.

The sampling method applied in this study is non-probability sampling method. Both 'quota' and 'judgment' sampling were used. In order to attain high level of representation of different levels of study (Diploma, Bachelor and Master), samples were taken equally from every level. Judgement was also used to select the class rooms where mostly international students were studying. The students in selected class rooms were requested to participate in the survey and the questionnaires were distributed and collected back in the same day. The total number of respondents is 263 which represent approximately $10 \%$ of the entire current population of the private educational institution. 


\subsection{Tests of Reliability and Validity}

In the survey, the necessary data were gathered using a questionnaire that elicits responses by using the attitude questions with itemized rating scale. The reliability of responses was checked by the reliability test, using the standard Cronbach's Alpha value, 0.6. In this study, the proposed methodology for identifying the motives based on the statements listed in the questionnaire is the test of the 'construct validity' through the factor analysis (component analysis with Varimax rotation). Similarly, the statements of service dimensions which are described to measure the expectations and actual experience of the service quality were tested with the factor analysis (component analysis with rotation). The existing statements of the SERVQUAL model (Barnes, 2007) and the newly added statements in the SERVQUAL model were validated through the factor analysis (component analysis with rotation). Likewise the motives, the validity of the statements of satisfaction were tested by means of the factor analysis.

\section{Empirical Study}

\subsection{Profile of Respondents}

The survey was carried out in the first two weeks of April, 2012 and the total number of respondents counted 263. The responses were coded and entered into the SPSS. Firstly, the selected demographic variables- gender, age, nationality, present level of study - of respondents are summarised as in Table 1. (Note: The total number varies from each other because of the missing data.)

The sample respondents can be seen as good representation of the population, as the data in Table 1 show a good coverage in terms of categories and the frequency number for each category. The respondents consist of both types of gender, wide range of age groups and various nationalities. Chinese, Indian, Indonesian, Vietnam and Malaysian are the largest groups of nationality and there are also many other nationalities from different continents (Asia, Europe, Africa and North America). The samples represent three levels of study, i.e. Diploma, Bachelor and Master.

Table 1. Profile of respondents

\begin{tabular}{lll}
\hline Variables & Frequency & Percentage \\
\hline Gender & 121 & \\
Male & 130 & 48.2 \\
Female & 251 & 51.8 \\
Total & & 100 \\
Age & 51 & \\
Below 20 & 165 & 20.7 \\
$20-24$ & 30 & 66.8 \\
$25-29$ & 1 & 12.46 \\
30 and above & 247 & 0.04 \\
Total & & 100 \\
Nationalities & 62 & \\
Chinese & 60 & 24.2 \\
Indian & 41 & 23.4 \\
Indonesian & 24 & 16.0 \\
Vietnamese & 14 & 9.4 \\
Malaysian & 55 & 5.5 \\
Others & 256 & 21.5 \\
Total & & 100 \\
Present Level of Study & 84 & 33.3 \\
Diploma & 74 & 29.4 \\
Bachelor & 94 & 37.3 \\
Master & 252 & 100 \\
Total & &
\end{tabular}

\subsection{Reliability of Data}

The survey results were checked for reliability and validity as mentioned in the research methodology. Firstly, the Cronbach's Alpha was found to be 0.7255 for the statements concerned with the motives of the study as 
listed in Table 2. The statements examining the motives of the study in Table 2 are actually the refined set of statements being different from the original set in the questionnaire. Two statements which could not fit into the presently specified four factors were dropped from further analysis. The remaining statements were grouped into four components as generated by the factor analysis. The resulting four components are: 1) academic and education, 2) work, 3) career \& migration, and 4) pleasure \& experience. The 'work' motive was found as the new factor in this study, in addition to the three motives specified in the literature by Wang (2004). The factor loading of each statement is also shown in Tab. 2 and it can be seen that the extent of the factor loading varies among the components.

The data on expectation and actual experiences were checked for the reliability and validity as in Table 3 . The reliability tests show that the scales applied in the measurement of 'Expectation' and 'Actual Experience' are reliable with the satisfactory level of Cronbach's Alpha value greater than 0.7. The validity of the measurement on the service quality was also checked with the help of the factor analysis (component analysis with rotation) and the factor loading values. After the analysis, 15 statements out of 32 original statements in service quality were excluded as they are weak in validity to represent the category of service quality concerned. The factor loading of statements in the respective components shows some variations within the components and between the components.

The measurement of the satisfaction was tested also in the same way as above and it was found that the statements are reliable in terms of the scale, and the factor loading of each statement is obviously high as shown in the Table 4.

Table 2. Reliability and validity of measurement scale (motives)

\begin{tabular}{|c|c|c|c|}
\hline No. & Motive / Statements & $\begin{array}{l}\text { Cronbach's } \\
\text { Alpha }=0.7255\end{array}$ & $\begin{array}{l}\text { Factor Loading } \\
(\text { KMO }=\mathbf{0 . 7 4 5 )}\end{array}$ \\
\hline 1 & Academic \& Education Quality & 0.7422 & \\
\hline a. & I decided to come to Singapore to obtain a good education. & & .816 \\
\hline b. & $\begin{array}{l}\text { I chose to come to Singapore because it is well-known for its } \\
\text { education quality. }\end{array}$ & & .814 \\
\hline c. & $\begin{array}{l}\text { I came to Singapore to study so that I may go as far as I can } \\
\text { in my educational career. }\end{array}$ & & 680 \\
\hline 2 & Work & 0.5706 & \\
\hline a. & $\begin{array}{l}\text { Before I came to Singapore, I heard that Singapore was a } \\
\text { land of opportunity for students like me to work while } \\
\text { studying. }\end{array}$ & & 0.454 \\
\hline b. & During my study here, I have already tried to find a job. & & 0.775 \\
\hline c. & $\begin{array}{l}\text { I need usually to get a job to help finance my study in } \\
\text { Singapore. }\end{array}$ & & 0.735 \\
\hline d. & $\begin{array}{l}\text { I wanted a course of study that allows me to gain work } \\
\text { experience while studying. }\end{array}$ & & 0.543 \\
\hline 3 & Career \& Migration & 0.6136 & \\
\hline a. & $\begin{array}{l}\text { Before I came to Singapore, I believed that it would be } \\
\text { possible for me to work in Singapore after graduation. }\end{array}$ & & 0.837 \\
\hline b. & I intend to find a job in Singapore after the graduation. & & 0.680 \\
\hline c. & $\begin{array}{l}\text { I chose Singapore as the country of my study abroad, } \\
\text { because it is a safe place. }\end{array}$ & & 0.517 \\
\hline 4 & Pleasure \& Experience & 0.4560 & \\
\hline a. & $\begin{array}{l}\text { I chose Singapore as the country of my study abroad, } \\
\text { because it is a fun place. }\end{array}$ & & 0.432 \\
\hline b. & $\begin{array}{l}\text { I came to Singapore because I believed that it is possible to } \\
\text { meet people from all over the world. }\end{array}$ & & .0 .461 \\
\hline c. & I have visited many places in Singapore while here. & & 0.749 \\
\hline d. & $\begin{array}{l}\text { I have travelled to other countries as a Singapore } \\
\text { international student pass holder. }\end{array}$ & & 0.610 \\
\hline
\end{tabular}


Table 3. Reliability and validity test of measurement scale (expectations and perceptions)

\begin{tabular}{|c|c|c|c|c|c|}
\hline \multirow{3}{*}{ No. } & \multirow{3}{*}{ Statements } & \multicolumn{2}{|l|}{ Expectations } & \multicolumn{2}{|l|}{ Perceptions } \\
\hline & & Cronbach's & Factor & Cronbach's & Factor \\
\hline & & $\begin{array}{l}\text { Alpha }= \\
0.9243\end{array}$ & $\begin{array}{l}\text { Loading } \\
(\mathrm{KMO}=0.897)\end{array}$ & $\begin{array}{l}\text { Alpha }= \\
0.9293\end{array}$ & $\begin{array}{l}\text { Loading } \\
(\mathrm{KMO}=0.905)\end{array}$ \\
\hline 1 & Responsiveness & 0.8618 & & 0.8324 & \\
\hline a. & $\begin{array}{l}\text { The school would provide prompt } \\
\text { service. }\end{array}$ & & 0.717 & & 0.577 \\
\hline b. & Staffs would be willing to help. & & 0.773 & & 0.609 \\
\hline c. & $\begin{array}{l}\text { The school would provide prompt } \\
\text { response to my requests. }\end{array}$ & & 0.745 & & 0.453 \\
\hline 2 & Assurance & 0.8129 & & 0.8162 & \\
\hline a. & $\begin{array}{l}\text { The school would be able to instil } \\
\text { confidence in the success in my study. }\end{array}$ & & 0.617 & & 0.577 \\
\hline b. & $\begin{array}{l}\text { The certificate or degree conferred by my } \\
\text { school would enable me to get a job } \\
\text { easily. }\end{array}$ & & 0.640 & & 0.592 \\
\hline c. & $\begin{array}{l}\text { The course of study that I undertake } \\
\text { would be popular. }\end{array}$ & & 0.556 & & 0.656 \\
\hline d. & $\begin{array}{l}\text { The course of study that I undertake } \\
\text { would be in high demand. }\end{array}$ & & 0.585 & & 0.702 \\
\hline 3 & Empathy & 0.7951 & & 0.7405 & \\
\hline a. & $\begin{array}{l}\text { Teaching staffs would be willing to } \\
\text { provide individual attention to students. }\end{array}$ & & 0.610 & & 0.709 \\
\hline b. & $\begin{array}{l}\text { Support staffs would always provide } \\
\text { individual attention to students. }\end{array}$ & & 0.680 & & 0.550 \\
\hline 4 & Tangibles & 0.8300 & & 0.7779 & \\
\hline a. & School staffs would be well dressed. & & 0.799 & & 0.729 \\
\hline b. & $\begin{array}{l}\text { School staffs would have a good } \\
\text { appearance. }\end{array}$ & & 0.814 & & 0.729 \\
\hline c. & $\begin{array}{l}\text { Materials used in the school would be } \\
\text { visually appealing. }\end{array}$ & & 0.618 & & 0.516 \\
\hline 5 & Reliability & 0.9092 & & 0.8894 & \\
\hline a. & $\begin{array}{l}\text { The school would always deliver services } \\
\text { on-time. }\end{array}$ & & 0.604 & & 0.624 \\
\hline b. & $\begin{array}{l}\text { The school would help students to solve } \\
\text { their problems. }\end{array}$ & & 0.755 & & 0.747 \\
\hline c. & $\begin{array}{l}\text { The school would perform right the first } \\
\text { time. }\end{array}$ & & 0.723 & & 0.802 \\
\hline d. & $\begin{array}{l}\text { The school would keep students } \\
\text { informed of events. }\end{array}$ & & 0.541 & & 0.708 \\
\hline e. & $\begin{array}{l}\text { The school would keep students } \\
\text { informed of its services. }\end{array}$ & & 0.560 & & 0.574 \\
\hline
\end{tabular}

Table 4. Reliability and validity test of measurement scale (satisfaction)

\begin{tabular}{|c|c|c|c|}
\hline No. & Statements & $\begin{array}{l}\text { Cronbach's } \\
\text { Alpha }=0.8649\end{array}$ & $\begin{array}{l}\text { Factor } \\
\text { Loading } \\
(\mathrm{KMO}=\mathbf{0 . 7 7 1 )}\end{array}$ \\
\hline & Overall & 0.8649 & \\
\hline a. & I think I made the right decision to study in Singapore. & & .770 \\
\hline b. & I think I made the right choice to study in MDIS. & & .883 \\
\hline c. & $\begin{array}{l}\text { I will recommend Singapore as study destination to my } \\
\text { friends. }\end{array}$ & & .761 \\
\hline d. & $\begin{array}{l}\text { I will recommend MDIS to my friends as the place to } \\
\text { study }\end{array}$ & & .871 \\
\hline e. & $\begin{array}{l}\text { I will continue to keep in touch with MDIS after my } \\
\text { studies. }\end{array}$ & & .746 \\
\hline
\end{tabular}




\section{Results}

\subsection{Motives of the International Students}

The responses given by the samples are summarized in Table 5. Figure 4 shows the means of four motives: academic \& education, work, career \& migration, and pleasure \& experience. Among them, the highest level of motive is found in the 'career \& migration' and the second highest level of motive is found in the 'academic \& education'. The 'pleasure \& experiential' motives is the third highest motive, followed by the work motive.

Table 5. Motivations (means \& standard deviation)

\begin{tabular}{llll}
\hline No. & Type & Mean & $\begin{array}{l}\text { Standard } \\
\text { Deviation }\end{array}$ \\
\hline 1 & Academic \& Education & 3.9272 & .63154 \\
2 & Work & 3.1314 & .79423 \\
3 & Career \& Migration & 3.9302 & .71628 \\
4 & Pleasure \& Experience & 3.4277 & .64637 \\
& Overall & 3.6125 & .46973 \\
\hline
\end{tabular}

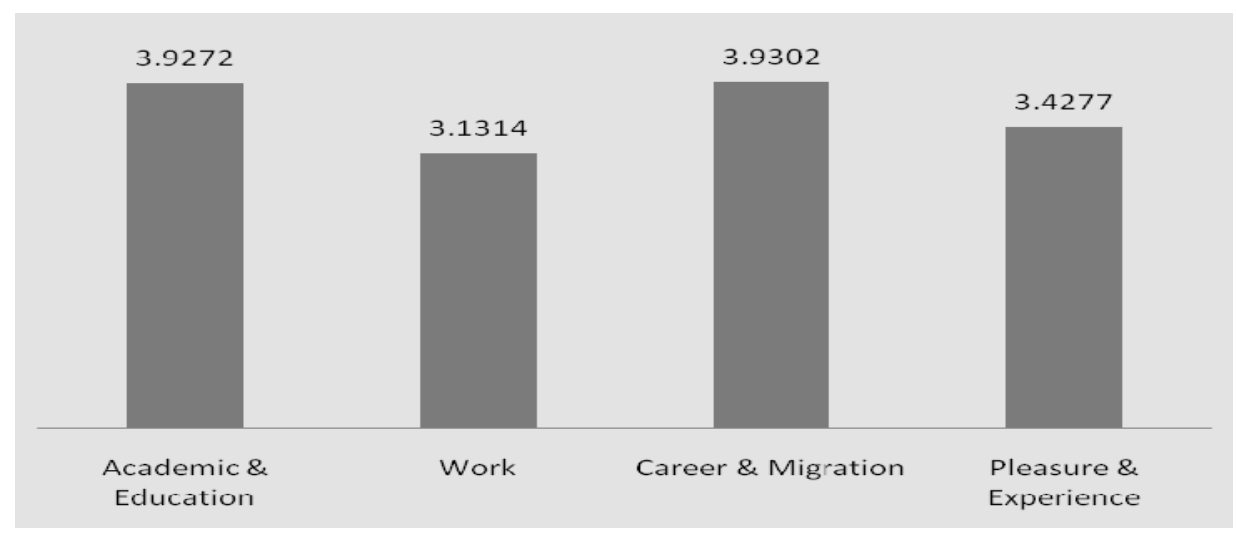

Figure 4. Means of Motives

As shown in Table 5, the motives of the students vary widely. Thehighest motive in terms of the means value can be determined by comparing the four means. The motive with the highest means value is treated as the 'primary motive' in this study, and the respondents are divided into four groups according to the primary motive. Table 6 as well as Figure 5 show the number of respondents which fall into four groups of primary motives. It can be seen that the largest group of sample international students $(47.9 \%)$ has the primary motive in 'career \& migration'. The 'academic \& education' is the second largest (30.3\%) and the third group of primary motive is 'pleasure \& experience'. The 'work' motive is the smallest group (5\%) if the motive to work in Singapore is counted as the primary motive.

Table 6. Primary motives

\begin{tabular}{llll}
\hline No. & Motive & Frequency & Percentage \\
\hline 1 & Academic/Education & 79 & 30.3 \\
2 & Work & 13 & 5.0 \\
3 & Career \& Migration & 125 & 47.9 \\
4 & Pleasure \& Experience & 44 & 16.9 \\
& Total & 261 & 100.0 \\
\hline
\end{tabular}




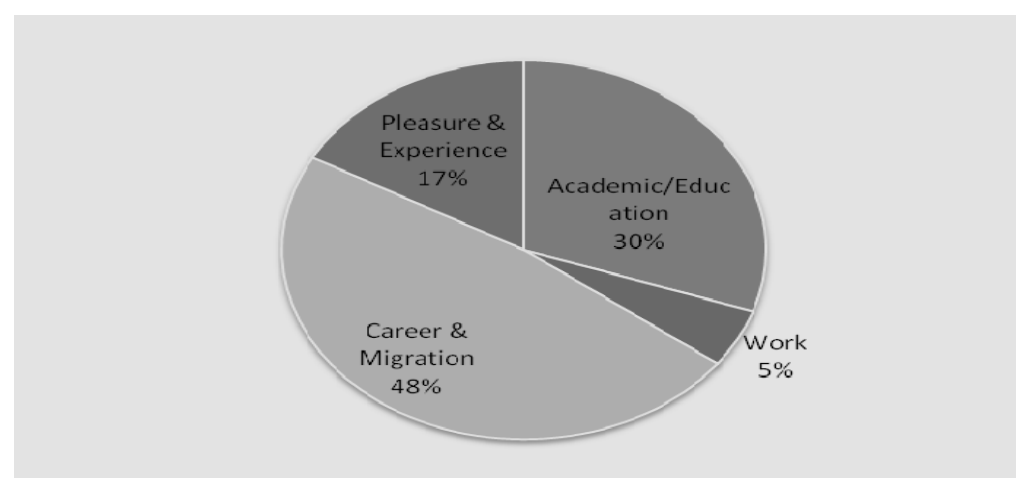

Figure 5. Primary motives

\subsection{Expectation and Perception}

As indicated by the SERVQUAL model by Zheitmal, Berry and Parasuraman (1993), service quality is usually evaluated by the gap between the expectation and the actual (perceived) level of service dimensions. Table 7 shows the gaps for each service dimension. The gaps are negative (i.e. actual experience is lower than the expectation) in all the dimensions. Except for the statement 4(b) in Table 7, all the gaps are statistically significant at $99 \%$ or $95 \%$ confidence level which is determined by means of the paired t-Test with the data from expected means and actual means. Moreover, the largest gap is found in the reliability $(-0.8)$.

Table 7. Service gap between expectation and actual experience (perception) by items

\begin{tabular}{|c|c|c|c|c|}
\hline No. & Statements & $\begin{array}{l}\text { Expectation } \\
\text { (1) }\end{array}$ & $\begin{array}{l}\text { Actual } \\
\text { Experience (2) }\end{array}$ & $\begin{array}{l}\text { Service } \\
\text { Gap }(2-1)\end{array}$ \\
\hline 1 & Responsiveness & 3.775 & 3.239 & $-0.536^{*}$ \\
\hline a. & The school would provide prompt service. & 3.64 & 3.19 & $-0.45^{*}$ \\
\hline b. & Staffs would be willing to help. & 3.87 & 3.38 & $-0.49 *$ \\
\hline c. & $\begin{array}{l}\text { The school would provide prompt response to my } \\
\text { requests. }\end{array}$ & 3.79 & 3.17 & $-0.62 *$ \\
\hline 2 & Assurance & 3.870 & 3.323 & $-0.547 *$ \\
\hline a. & $\begin{array}{l}\text { The school would be able to instil confidence in the } \\
\text { success in my study. }\end{array}$ & 3.69 & 3.29 & $-0.4^{*}$ \\
\hline b. & $\begin{array}{l}\text { The certificate or degree conferred by my school would } \\
\text { enable me to get a job easily. }\end{array}$ & 3.95 & 3.17 & $-0.78^{*}$ \\
\hline c. & The course of study that I undertake would be popular. & 3.90 & 3.48 & $-0.42 *$ \\
\hline d. & $\begin{array}{l}\text { The course of study that I undertake would be in high } \\
\text { demand. }\end{array}$ & 3.93 & 3.38 & $-0.55^{*}$ \\
\hline 3 & Empathy & 3.668 & 3.246 & $-0.422 *$ \\
\hline a. & $\begin{array}{l}\text { Teaching staffs would be willing to provide individual } \\
\text { attention to students. }\end{array}$ & 3.69 & 3.31 & $-0.38^{*}$ \\
\hline b. & $\begin{array}{l}\text { Support staffs would always provide individual } \\
\text { attention to students. }\end{array}$ & 3.65 & 3.18 & $-0.47^{*}$ \\
\hline 4 & Tangibles & 3.741 & 3.431 & $-0.31 *$ \\
\hline a. & School staffs would be well dressed. & 3.71 & 3.56 & $-0.15^{* *}$ \\
\hline b. & School staffs would have a good appearance. & 3.63 & 3.49 & -0.14 \\
\hline c. & $\begin{array}{l}\text { Materials used in the school would be visually } \\
\text { appealing. }\end{array}$ & 3.88 & 3.25 & $-0.63^{*}$ \\
\hline 5 & Reliability & 3.992 & 3.125 & $-0.867 *$ \\
\hline a. & The school would always deliver services on-time. & 3.87 & 3.07 & $-0.8^{*}$ \\
\hline b. & The school would help students to solve their problems. & 3.88 & 3.11 & $-0.77 *$ \\
\hline c. & The school would perform right the first time. & 3.92 & 3.13 & $-0.79 *$ \\
\hline d. & The school would keep students informed of events. & 3.85 & 3.27 & $-0.58^{*}$ \\
\hline e. & $\begin{array}{l}\text { The school would keep students informed of its } \\
\text { services. }\end{array}$ & 3.95 & 3.19 & $-0.76^{*}$ \\
\hline
\end{tabular}

*paired t-test significant at $(\mathrm{p}<0.01)$

** paired t-test significant at $(\mathrm{p}<0.05)$ 


\subsection{Satisfaction}

The survey produced the overall satisfaction level, 3.3211 which is slightly above the average level, 3.0. The satisfaction level can be examined in detail by statements as shown in Table 8 . The respondents were satisfied with the decision to study in Singapore. However, when asked if they would recommend the private school under study, the mean score was only 3.11, which is the lowest among the satisfaction levels.

Table 8. Satisfaction

\begin{tabular}{llll}
\hline No. & Statement & Mean & Standard Deviation \\
\hline 1 & $\begin{array}{l}\text { I think I made the right decision to study in } \\
\text { Singapore. }\end{array}$ & 1.06 \\
2 & $\begin{array}{l}\text { I think I made the right choice to study in } \\
\text { MDIS. }\end{array}$ & 1.21 \\
3 & $\begin{array}{l}\text { I will recommend Singapore as study } \\
\text { destination to my friends. }\end{array}$ & .974 \\
4 & $\begin{array}{l}\text { I will recommend MDIS to my friends as the } \\
\text { place to study }\end{array}$ & 1.004 \\
I will continue to keep in touch with MDIS & 3.14 & 1.079 \\
after my studies. & 3.3211 & .82654 \\
\hline
\end{tabular}

\section{Hypothesis Testing}

H1: International students studying in Singapore private higher education hold significantly different motives of study. (The levels of motives of study differ from each other.)

The hypothesis that the motives of a student are different from each other can be tested by non-parametric (K-related samples) test, particularly by Friedman test. The test result confirms that the motives differ in their ranks with the asymptotic significant level, $\mathrm{p}=0.000$, thus the hypothesis is accepted.

H2A: Expectation of service quality is related to the motive of study. (The higher the level of motive, the higher is the level of expectation on service quality.)

To test that the expectation on the service quality in five dimensions (responsiveness, assurance, empathy, tangibles and reliability) is related to the level of motives, the simple correlation method (Pearson Correlation with two-tailed test) is applied. The correlation coefficients are shown in Table 9. Firstly, the overall expectation and the overall motive relate positively to each other significantly $(\mathrm{p}<0.05)$, but the magnitude of correlation is rather weak (0.178). Among them, the two motives, namely 'academic \& education' and the 'career \& migration', have relatively strong correlations with the overall expectation. The other two, 'work' motive and 'pleasure \& migration' motive, are insignificant in the relationship with the overall expectation. Secondly, when considering the specific types of motives which have relatively strong relationships with the service dimensions, it is found that 'academic \& education' motive has a relatively strong correlation with responsiveness and reliability. The dimension, tangibles in the service quality, is significantly related to the 'work' motive. 'Career and migration' motive has some relationships with responsiveness, assurance and reliability. The 'pleasure \& experience' motive has significant, but weak, positive relationships with all the service elements except reliability. Overall, it is found that the individual motives have a weak and positive correlation with some of the dimensions. Hence, the hypothesis that the expectation of the service quality is related with the level of a particular motive cannot be rejected. 
Table 9. Correlation between motives and expectations (significance level)

\begin{tabular}{|c|c|c|c|c|c|c|c|c|c|c|c|c|c|}
\hline \multirow[t]{2}{*}{ No. } & \multirow[t]{2}{*}{ Motives } & \multicolumn{7}{|l|}{ Expectations } & \multicolumn{5}{|c|}{ Actual Experience } \\
\hline & & Responsiveness & Assurance & Empathy & Tangibles & Reliability & Overall & Responsiveness & Assurance & Empathy & Tangibles & Reliability & Total \\
\hline \multirow[t]{2}{*}{1} & Academic/ & $0.214^{*}$ & $0.188^{*}$ & 0.179 & 0.106 & $0.202 *$ & $0.246^{*}$ & $0.161^{*}$ & $0.178^{*}$ & $0.197^{*}$ & $0.276^{*}$ & $0.340^{*}$ & $0.348^{*}$ \\
\hline & Education & $(0.001)$ & $(0.003)$ & $(0.005)$ & $(0.096)$ & $(0.013)$ & $(0.003)$ & $(0.013)$ & $(0.007)$ & $(0.002)$ & $(0.000)$ & $(0.000)$ & $(0.000)$ \\
\hline \multirow[t]{2}{*}{2} & Work & -0.013 & -0.019 & 0.022 & $0.192^{*}$ & -0.007 & 0.031 & 0.117 & $0.142^{*}$ & 0.113 & 0.055 & 0.184 & $0.202 *$ \\
\hline & & $(0.832)$ & $(0.370)$ & $(0.728)$ & $(0.022)$ & $(0.930)$ & $(0.700)$ & $(0.069)$ & $(0.032)$ & $(0.080)$ & $(0.400)$ & $(0.029)$ & $(0.018)$ \\
\hline \multirow[t]{2}{*}{3} & Career/ & 0.159 & $0.145^{*}$ & $0.098^{*}$ & $0.034^{*}$ & $0.205^{*}$ & $0.191^{*}$ & $0.202 *$ & $0.206^{*}$ & 0.126 & $0.189^{*}$ & 0.227 & $0.284^{*}$ \\
\hline & Migration & $(0.012)$ & $(0.023)$ & $(0.124)$ & $(0.595)$ & $(0.012)$ & $(0.020)$ & $(0.002)$ & $(0.002)$ & $(0.049)$ & $(0.003)$ & $(0.007)$ & $(0.001)$ \\
\hline \multirow[t]{4}{*}{4} & Pleasure/ & $0.171^{*}$ & $0.126^{*}$ & $0.161^{*}$ & $0.124^{*}$ & 0.127 & $0.217^{*}$ & 0.056 & 0.090 & $0.143^{*}$ & -0.003 & 0.209 & $0.183^{*}$ \\
\hline & Experience & $(0.007)$ & $(0.047)$ & $(0.010)$ & $(0.049)$ & $(0.113)$ & $(0.007)$ & $(0.242)$ & $(0.173)$ & $(0.027)$ & $(0.963)$ & $(0.013)$ & $(0.032)$ \\
\hline & Overall & 0.075 & 0.080 & 0.119 & $0.215^{*}$ & 0.114 & $0.178^{*}$ & 0.184 & 0.211 & 0.176 & 0.190 & 0.342 & $0.361^{*}$ \\
\hline & & $(0.253)$ & $(0.224)$ & $(0.069)$ & $(0.001)$ & $(0.174)$ & $(0.033)$ & $(0.005)$ & $(0.002)$ & $(0.008)$ & $(0.004)$ & $(0.000)$ & $(0.000)$ \\
\hline
\end{tabular}

*ANOVA significant at $(\mathrm{p}<0.05)$

H2B: Perception of service quality is related to the motive of study. (The higher the level of motive, the higher is the perceived level of service quality.)

Similar to the previous hypothesis, the simple correlations between the motives and the actual experience (perceived service quality) are examined. The results are shown in Tab. 9. The overall relationship between the motives and actual experiences (perceptions) is significantly positive and stronger than that between the overall motive and the overall expectation. It is also found that the individual types of motives are related relatively stronger and positively with the overall actual experience. The 'career \& migration' motive and 'academic \& education' motives are significantly and positively correlated with the service dimensions, whereas the 'pleasure $\&$ experience' motive and work motive show significant and positive correlations with the reliability. Overall, the null hypothesis about the relationships between the motives and the actual experience (perception) of service quality cannot be rejected.

H2C: Service gap is related to the motive of study. (The higher the level of motive, the lower is the gap of service.)

The service gap (measured by the difference between the actual experience and the expectation) is calculated and verified in relationship with the types of motives. The correlation coefficients of the motives and service gap are shown also in Table 10. Significant relationships are found between academic \& education and tangibles, and between career \& migration and reliability. In the case of the former, the stronger the academic \& education motive, the narrower is the gap in the tangibles of the service quality. For the latter, the more career $\&$ migration oriented, the larger is the score in the reliability of the service quality. At the overall level of motive, there is a significant, but very weak, correlation at the tangibles. Except for these significant correlations, all others are not significant. Thus, overall, the null hypothesis cannot be accepted.

Table 10. Motives' correlations with service gap and overall satisfaction (significance levels)

\begin{tabular}{|c|c|c|c|c|c|c|c|c|}
\hline \multirow[t]{2}{*}{ No. } & \multirow[t]{2}{*}{ Motives } & \multicolumn{6}{|l|}{ Service Gap } & \multirow{2}{*}{$\begin{array}{l}\text { Overall } \\
\text { Satisfaction }\end{array}$} \\
\hline & & Responsiveness & Assurance & Empathy & Tangibles & Reliability & Total & \\
\hline 1 & Academic/ & -0.041 & -0.003 & 0.017 & $0.132 *$ & 0.040 & 0.051 & 0.351 \\
\hline & Education & $(0.528)$ & $(0.962)$ & $(0.790)$ & $(0.044)$ & $(0.662)$ & $(0.583)$ & $(0.000)^{* *}$ \\
\hline 2 & Work & $\begin{array}{l}0.096 \\
(0.141)\end{array}$ & $\begin{array}{l}0.131^{*} \\
(0.050)\end{array}$ & $\begin{array}{l}0.086 \\
(0.184)\end{array}$ & $\begin{array}{l}-0.107 \\
(0.111)\end{array}$ & $\begin{array}{l}0.056 \\
(0.535)\end{array}$ & $\begin{array}{l}0.082 \\
(0.363)\end{array}$ & $\begin{array}{l}0.035 \\
(0.579)\end{array}$ \\
\hline 3 & $\begin{array}{l}\text { Career/ } \\
\text { Migration }\end{array}$ & $\begin{array}{l}0.045 \\
(0.491)\end{array}$ & $\begin{array}{l}-0.030 \\
(0.657)\end{array}$ & $\begin{array}{l}-.066 \\
(0.304)\end{array}$ & $\begin{array}{l}-0.001 \\
(0.989)\end{array}$ & $\begin{array}{l}-0.158^{*} \\
(0.076)\end{array}$ & $\begin{array}{l}-0.138 \\
(0.127)\end{array}$ & $\begin{array}{l}0.240 \\
(0.000)^{* *}\end{array}$ \\
\hline 4 & $\begin{array}{l}\text { Pleasure/ } \\
\text { Experience } \\
\text { Overall }\end{array}$ & $\begin{array}{l}-0.091 \\
(0.161) \\
0.027 \\
(0.682) \\
\end{array}$ & $\begin{array}{l}-0.037 \\
(0.634) \\
0.031 \\
(0.652) \\
\end{array}$ & $\begin{array}{l}0.006 \\
(0.929) \\
0.003 \\
(0.964) \\
\end{array}$ & $\begin{array}{l}-0.088 \\
(0.179) \\
-0.005^{*} \\
(0.937) \\
\end{array}$ & $\begin{array}{l}-0.041 \\
(0.650) \\
-.0030 \\
(0.742) \\
\end{array}$ & $\begin{array}{l}-0.123 \\
(0.174) \\
-0.038 \\
(0.686) \\
\end{array}$ & $\begin{array}{l}0.227 \\
(0.000) * * \\
0.286 \\
(0.000)^{* *}\end{array}$ \\
\hline
\end{tabular}

*ANOVA significant at $(\mathrm{p}<0.05)$

***ANOVA significant at $(\mathrm{p}<0.01)$ 
H2D: Satisfaction level is related to the motive of study. (The higher the level of motive, the higher is the level of satisfaction).

The relationships between the motives and the overall satisfaction level are examined using the same method, simple correlation. The results are also shown in Table 10. Positive and relatively strong correlations exist in overall and individual motives, except the work motive. It is found that the academic \& education and overall satisfaction are (relatively) strongly and positively correlated. The career \& migration motive can be seen as a factor contributing to the overall satisfaction after academic/education, followed by the pleasure $\&$ experience motive. Thus, the hypothesis cannot be rejected in general.

H3: The satisfaction is related to the service quality measured by the gap. (The narrower the gap in the service quality, the higher is the satisfaction).

The relationship between the service gap (the difference between the actual experience and the expectation) and satisfaction is tested with the simple correlation and the results are shown in Table 11. It is found that the service gaps (in minus sign) and the satisfaction level are positively and significantly correlated, although the magnitude is small. This means that the smaller the service gap, the higher is the level of overall satisfaction. The strong correlations are found in the assurance and responsiveness. Therefore, the null hypothesis cannot be rejected.

Table 11. Correlations between service gaps and overall satisfaction (significance level)

\begin{tabular}{lll}
\hline No. & Service Gaps & Overall Satisfaction \\
\hline 1 & Responsiveness & 0.279 \\
& & $(0.001)$ \\
2 & Assurance & 0.312 \\
& & $(0.000)$ \\
3 & Empathy & 0.262 \\
& & $(0.000)$ \\
4 & Tangibles & 0.218 \\
& & $(0.001)$ \\
5 & Reliability & 0.238 \\
& & $(0.007)$ \\
& Overall & 0.282 \\
& & $(0.001)$ \\
\hline
\end{tabular}

\section{Findings}

This empirical study identifies four motives for studying abroad held by the international students studying in Singapore, particularly in the private education institution of our study. The motives discovered by the factor analysis are: 1) academic/education, 2) work, 3) career \& migration, and 4) pleasure \& experience. The study has found an additional motive, namely 'work' motive, which was not included in the Wang (2004)'s typology reviewed in the literature. The study has found, as indicated in the hypothesis tests, that the motives have positive relationships with the dimensions of service quality in both expectations and actual experiences. Moreover, there is a relatively stronger relationship between the level of motive of the study and the level of satisfaction. However, it does not show significant relationship between the motives and service gap.

The study has found clearly that the level of the motive in general has considerable impacts on both expectation and perception with each dimension of service quality. There are also specific patterns and degrees of influence by each type of motive. The 'academic \& education' motive showed consistently strong interest and sensitivity to every dimension. A high level of motive in 'academic \& education' can also increase the service gap and the level of satisfaction as well. Thus, the 'academic \& education' motive is a powerful and essential motive in determining the service quality and the overall satisfaction of international student. The higher level in the 'academic \& education' motive can help the higher education institutions to achieve higher level of service quality and satisfaction than the other motives. The 'career \& migration' motive has shown some key areas of service quality; this motive has higher impacts and sensitivities in responsiveness, assurance and tangibles.

The results have shown that the respondents in the current study felt that the actual service quality is obviously below their expectations. The study has found a positive relationship between the service gaps (in the sense of narrow gap) with the overall satisfaction with the service. The service gaps are found to be unrelated with the 
motives. However, the service gaps are still important in determining the satisfaction with the service. In the investigation of the relationships between the service gaps and the overall satisfaction, positive and significant correlations in all kinds of gaps are found. The correlation coefficients are also found to be higher than any others in the whole study. Interestingly, it has been found that the overall satisfaction with the service is significantly and positively correlated with all the motives.

\section{Discussion and Marketing Implications}

The empirical results have supported the influence of motives in the service quality assessment and satisfaction with the service. The study reveals that the motives of the international students in selecting country and institution have some consequent impacts on their expectation, perception and satisfaction. Marketers of higher education programmes should therefore take into account the motives of the international students in formulating and executing their programmes.

First of all, every marketing programme needs to be developed according to the motives of each target market. For example, the academic quality and standards should be emphasized for the segment in which the students are willing to acquire education of high quality and high standards. However, programmes which aim to accommodate students with the 'work' motive need a feature of flexibility within the study plan and the scheduling of classes.

From the results, it has been found that the international students came to Singapore and to the school under study with higher expectations than the actual experience (perception). The greater expectation over the actual experience has resulted in the service gaps in all the service dimensions: responsiveness, assurance, empathy, tangibility and reliability. The highest gap has been found in the 'reliability' dimension. Hence, academic institutions must pay attention towards those service elements concerned with the 'reliability' dimension. This dimension can be improved through systematic and effective communication. The service system should be reviewed in order to ensure that the communication and relationship between the school and the international students are seamless and effective. Country managers and overseas agents should also ensure these expectations are managed and reasonable.

An important dimension of the service quality is found to be 'assurance' especially in the perceived service quality (refer to Tab. 9), which correlates relatively strongly with the motives. Assurance is the major concern for some students, especially those with the 'academic \& education' and 'career \& migration' motives, while the other students are not much concerned with this service dimension. The main concern with the 'assurance' dimension is the recognition of the quality of the programme. Hence, the marketing programme must ensure promotion activities of the products will enhance the value of the degree or certificates awarded to the international students. In fact, we have to consider and understand the seriousness of the international students studying abroad. They pursue quality education and/or degree for their future, sacrificing significant time, efforts, and funds. The quality and high standards in educational services are thus essential to their satisfaction.

In contrast to the 'serious' students with strong motives in 'academic \& education' and / or 'career \& migration', the other motives are more concerned with either experience or immediate job opportunities. Satisfying students who harbour such motives needs some special features of the education programme such as variety of school activities, internship programmes, flexible learning programme with independent learning, etc.

Marketers of higher education programmes can take into account the differences in the motives among the international students when developing the market segments. The market segmentation can be based on the psychographic and lifestyle variables, including the motives identified in this study. Appropriate educational service programmes can be developed to meet the expectations of each segment. The recruiters and consultants in the higher education institutions should use the expected characteristics of potential students of each programme. This will allow the concept of the market orientation to be effectively implemented in the education industry, particularly private organizations. The motive based approach of marketing will ensure good fit between the programme and the students and consequently, the prime goals of the international students can be achieved and actual satisfaction with their study will be realized. Higher education institutions hosting such international students can thus be successful with greater certainty.

\section{Conclusion}

The study has shown the four kinds of motives held by international students in pursuing private higher education in Singapore. It also found that the motives for their study have impact on the expectations on the service quality and perception of the services. The appropriate approach for marketers of higher education programme targeting international students is to design the programmes which match the patterns of motives of 
international students. The 'mismatch' can cause a lower satisfaction level. The increasing competition among the higher education institutions and the rising demand of international students on providers of higher educational services imply a sharper focus is required on the international students' needs and motives held before they make their final decisions concerning the destination and educational institution for their studies.

\section{Suggestion for Future Research}

The study was conducted in only one private higher education institute in Singapore. To represent the whole country market, the study should be extended into other PEIs as well as government institutions such as universities and polytechnics. To be able to generalize further and to meet the criteria of the external validity, similar research activities should be undertaken across key host countries of higher education for the international students.

\section{References}

Andrade, M. S. (2006). International students in English-speaking universities: Adjustment factors. Journal of Research in International Education, 5(2), 131-154. http://dx.doi.org/10.1177\%2F1475240906065589

Arambewela, R., \& Hall, J. (2006). A Comparative Analysis of International Education Satisfaction using SERVQUAL. Journal of Services Research, 6, Special Issue (July), 142-163. Retrieved from http://dro.deakin.edu.au/eserv/DU:30003511/arambewela-comparativeanalysisof-2006.pdf

Arora, V. (2007). International Students' Motivations for Studying in UK Higher Education: Understanding Choice and decision-making process of Indian Students. Dissertation. Retrieved from http://edissertations.nottingham.ac.uk

Atrek, B. (2010). Testing the Superiority and Dimensionality of SERVQUAL vs. SERVPREF in Higher Education. Quality Management Journal, 17(1), 47-59.

Baier, H. J. D. (2009). Internationalization of Higher Education: A Comparative Study of Foreign Students at BTU Cottbus vs. Other German Universities. Forum der Forschung, 22, 67-76. Retrieved from http://www-docs.tu-cottbus.de/pressestelle/public/Forum_der_Forschung/Heft_22/067-076-SCREEN.pdf

Barnes, B. R. (2007). Analyzing Service Quality: The Case of Post-graduate Chinese Students. Total Quality Management, 18(3), 313-331. http://dx.doi.org/10.1080\%2F14783360601152558

Bjarnason, S., Cheng, K-M., Fielden, J., Lemaitre, M-J., Levy, D., \& Varghese, N. V. (2009). A New Dynamic: Private Higher Education. UNESCO: World Conference on Higher Education 2009. Retrieved from http://unesdoc.unesco.org

British Council. (2008). International Student Mobility in East Asia; Executive Summary. Prepared by JNT Education. Retrieved from http://www.eahep.org.

Chatterjee, A., Ghosh, C., \& Bandyopadhyay, S. (2009). Assessing student's rating in higher education: A SERVQUAL approach. Total Quality Management \& Business Excellence, 20(10), 1095-1109. http://dx.doi.org/10.1080\%2F14783360903247114

Choudaha, R., \& Chang, L. (2012). Trends in International Students Mobility: Research Report. Research and Advisory Services: World Education Service, Spring 2012. Retrieved from http://www.wes.org

Gupta, A. (2005). International Trends in Private Higher Education and the Indian Scenario. Research and Occasional Paper Series. University of California, Berkeley. Retrieved from http://cshe.berkeley.edu

Hammond, K. L., Webster, R. L., \& Harmon, H. A. (2006). Market Orientation, Top Management Emphasis and Performance within University Schools of Business: Implication for Universities. Journal of Marketing Theory and Practice, 14(1), 69-85. http://dx.doi.org/10.2753\%2FMTP1069-6679140105

Harman, G. (2004). New Directions in Internationalizing Higher Education: Australia's Development as an Exporter of Higher Education Services. Higher Education Policy, 17, 101-120. http://dx.doi.org/10.1057\%2Fpalgrave.hep.8300044

Katty, L. F. C., Catherine, C. S. K., \& Tin, L. G. (2009). Perceptions affecting PRC Students motivation in a Singapore Private Institution. ERAS Conference 2009: Upgrading Teaching and Learning through Education Research, 19-20 Nov. 2009, NIE/NTU. Retrieved from http://hdl.handle.net/10497/878

Kritz, M. M. (2006). Globalization and Internationalization of Tertiary Education. International Symposium on International Migration and Development: Turin, Italy, 28-30 June 2006. Retrieved from http://www.un.org 
McClure, J. W. (2007). International graduates' cross-cultural adjustment: Experiences, coping strategies, and suggested programmatic responses. Teaching in Higher Education, 12(2), 199-217. http://dx.doi.org/10.1080\%2F13562510701191976

Michael, S., \& Pamela, R. (2008). Using SERVQUAL to Measure the Quality of the Classroom Experience. Decision Sciences Journal of Innovative Education, 6(1), 115-133. Retrieved from http://werken.ubiobio.cl/html/documentos/articulos_bibliografia_calidad_educacion_superior/calidad_servi cio_educacion_superior/csedsup_17.pdf

MITC. (2010). Vietnam: Attracting Foreign Students to Maine. Retrieved from http://www.mitc.com

Parasuraman, A. Zeithaml, V. A., \& Berry, L. L. (1988). SERVQUAL: A Multiple Item Scale for measuring Service Quality. Journal of Retailing, 64(1), 12-40. Retrieved from http://areas.kenan-flagler.unc.edu/Marketing/FacultyStaff/zeithaml/Selected\%20Publications/SERVQUAL$\% 20 \mathrm{~A} \% 20$ Multiple-Item $\% 20$ Scale $\% 20$ for $\% 20$ Measuring\%20Consumer\%20Perceptions\%20of\%20Service $\% 20$ Quality.pdf

Parasuraman, A., Zeithaml, V. A., \& Berry, L. L. (1985). A Conceptual Model of Service Quality and its Implications for future research. Journal of Marketing, 49, 41-50. http://dx.doi.org/10.2307\%2F1251430

Perkinson, R. (2006). International Higher Education - Seizing the opportunity for innovation and international responsibility, Plenary Speech presented to 'Global 2' Education Conference, held in Edinburgh, 7-8 December 2006. Retrieved from http://ihe.britishcouncil.org

Poh, H. J., \& Townsend, P. (2008). An Exploratory Study of International Students studying and living in a Regional Area. Journal of Marketing for Higher Education, 18(2), 240-263.

Rindfresh, J. M. (2003). Segment Profiling; Reducing Strategic Risk in Higher Education Management. Journal of Higher Education Policy and Management, 25(2), 147-159.

Sanders, P., Stevenson, K., King, M., \& Coates, D. (2000). University Student's expectations of teaching. Studies in Higher Education, 25(3), 309-329. http://dx.doi.org/10.1080\%2F03075070050193433

Shekarchizadeh, A., Rash, A., \& Hon-Tat, H. (2011). SERVQUAL in Malaysian Universities: Perspectives of International Students. Business Process Management Journal, 17(1), 67-81.

Sherry, M., Thomas, P., \& Chui, W. H. (2009). International students: a vulnerable student population. High Educ (2010), 60, 33-46. http://dx.doi.org/10.1007/s10734-009-9284-z

Singapore Education. (2006). Retrieved on September 1, 2012, from http://www.singaporeedu.gov.sg/htm/stu/stu05.htm

UIS (UNESCO Institute for Statistics). (2012). Table 17: Inbound mobility rate, female percentage, and sums of internationally mobile students in tertiary education by host country and continent of origin (ISCED 5 and 6). Beyond 20/20 WDS - Report Folders. Retrieved from http://stats.uis.unesco.org/unesco/TableViewer/tableView.aspx?ReportId=170

Vincent-Lancrin, S. (2008). Student Mobility, Internationalization of Higher Education and Skilled Migration. World Migration 2008 (Chapter 4, pp. 105-125). Retrieved from http://www.iom.int/jahia/webdav/site/myjahiasite/shared/shared/mainsite/published_docs/studies_and_repo rts/WMR2008/Ch4_WMR08.pdf.

Wang, Y. (2004). Pursuing Cross Cultural Education: A Multifaceted Investigation. International Education, 33(2), Knoxiville.

Zheitmal, V., Berry, L., \& Parasuraman, A. (1993). The nature and determinant of customer expectation of service quality. Journal of the Academy of Marketing Science, 21, 1-12. http://dx.doi.org/10.1177/0092070393211001 